\title{
Segmentation of electricity market for households in Slovenia
}

\author{
Štefan Bojnec, Drago Papler \\ (Faculty of Management Koper, University of Primorska, Koper SI-6104, Slovenia)
}

\begin{abstract}
This paper investigates the electricity market for households in Slovenia. The focus is on the investigation of some empirical facts in the Slovenian electricity market for households focusing on market segmentation, market concentration measures, real electricity price developments, and their implications for electrical energy consumption and consumer welfare. The authors apply descriptive statistics, Lorenz curve and Gini coefficient of concentration, and demand function using regression framework on time-series data. The authors found that the market liberalization and entry of new competitors have slightly caused variations in the patterns in real electricity price developments. Households' real income and real electricity prices for households are found as the crucial determinants for the electrical energy demands by households.
\end{abstract}

Key words: electricity market; market segmentation; market concentration; demand function; Slovenia

\section{Introduction}

The previous research has largely focused on the deregulation and liberalisation of the Slovenian electricity markets for industrial users (Bojnec \& Papler, 2005a, 2005b, 2006a, 2006b, 2007, 2010; Papler \& Bojnec, 2006, 2007). Since July in 2007, when the Slovenian electricity markets for households were deregulated and liberalised, the Slovenian electricity markets have been deregulated and liberalised for different electricity users. In this paper, the authors focus on the households' electricity markets in Slovenia, their market segmentations, market concentration and patterns in real consumer price developments for different households' electrical energy tariffs users and their impacts on electrical energy demand with their consequences for consumer welfare (Green, 2003; Nillesen, et al., 2004). These new empirical results with insights to the Slovenian households' electricity markets are also the main contributions of this paper.

The rest of the paper is structured in the following way. First, the authors briefly present methodology used. After that, the authors present empirical results on some empirical stylized facts on the Slovenian electricity markets for households focusing on market segmentation and market concentration measures, electricity prices for households and demand function for electricity consumption by households. The final section derives main conclusions and policy implications.

\section{Methodology}

As the methods of the empirical analyses, the authors apply the summary statistics on time-series data

Štefan Bojnec, Ph.D. of economics and full professor of economics, Faculty of Management Koper, University of Primorska; research fields: economics, international economics, management, various aspects of transformation processes, economics and business in transition Central and Eastern European countries, European integration, industrial management, dynamics of firms and labor, electricity, labor and other market analysis.

Drago Papler, MSc., Ph.D. candidate, Faculty of Management Koper, University of Primorska; research fields: electricity market deregulation, price liberalization, renewable sources of energies and sustainable electricity sector development. 
developments, measures of market concentration (Lorenz curve and Gini coefficient of concentration) and regressions analysis on time-series data (Norušis, 2002) to estimate demand function for electricity consumption by households in Slovenia. The authors expect that demand for electrical energy by households $\left(D_{h}\right)$ is positively associated with the real households' income, which is expressed by real wages $\left(W_{h}\right)$, negatively associated with the real price of electrical energy for households for a higher tariff rate $\left(P_{h-H T}\right)$, positively associated with real price of substitutes for gas price for households $\left(P_{h-g}\right)$ or oil price for households $\left(P_{o}\right)$, as well as negatively associated with the dummy variable for liberalisation of the electrical energy (dummy) or the Gini coefficient for concentration of the households users $\left(G_{h}\right)$ :

$$
D_{h}=f\left(W_{h}, P_{h-H T}, P_{h-g}, P_{o}, \text { dummy, } G_{h}\right)
$$

The authors use statistical data and data obtained from the retail electricity distribution enterprises in Slovenia. As a deflator for deflation of the nominal aggregates, the authors use the consumer price index obtained from the Statistical Office of the Republic of Slovenia. For testing the hypothesis for electrical energy demands by households, the authors use the ordinary least square method.

\section{Empirical results}

\subsection{Some stylized empirical facts on electricity markets for households in Slovenia}

The focus of the empirical analyses is on the patterns in consumption of electrical energy by households, market segmentation by the size of electrical energy consumption and on concentration of households by the size of electrical energy consumption, on development of real consumer prices and on demands for electricity by households in Slovenia.

\subsubsection{Patterns in electricity consumption by households}

Consumption of the electrical energy by households represents around one-third in the sale structure of the Slovenian electricity distribution enterprises. Between 1980 and 2008, consumption of the electrical energy by the Slovenian households has increased by $83.5 \%$ (see Table 1 and Fig. 1). The rapid increase in electricity consumption by the Slovenian households is seen during the years 1980-1985, 1990-1995, and during the most recent years. The increases in the real households' incomes are among the major driving forces for these increases in the household electricity consumption.

Table 1 Electricity consumption by the Slovenian households, 1980-2008

\begin{tabular}{cccccc}
\hline & $\begin{array}{c}\text { Yt: } \\
\text { Total consumption }(\mathrm{GWh})\end{array}$ & $\begin{array}{c}\text { It: } \\
\text { Base index }(1980=100)\end{array}$ & $\begin{array}{c}\text { Vt: } \\
\text { Chain index }\end{array}$ & $\begin{array}{c}\text { Kt: } \\
\text { Coefficient of dynamics }\end{array}$ & $\begin{array}{c}\text { St: } \\
\text { Rate of growth }\end{array}$ \\
\hline 1980 & $1,738.3$ & 100.0 & 100.0 & - & - \\
1985 & $2,057.2$ & 118.3 & 118.3 & 1.18 & 18.3 \\
1990 & $2,234.0$ & 128.5 & 108.6 & 1.09 & 8.6 \\
1995 & $2,550.2$ & 146.7 & 114.2 & 1.14 & 14.2 \\
2000 & $2,579.4$ & 148.4 & 101.1 & 1.01 & 1.1 \\
2005 & $2,934.7$ & 168.8 & 113.8 & 1.15 & 13.8 \\
2008 & $3,189.1$ & 183.5 & 108.7 & 1.09 & 8.7 \\
\hline
\end{tabular}

Data source: Authors' calculations. 


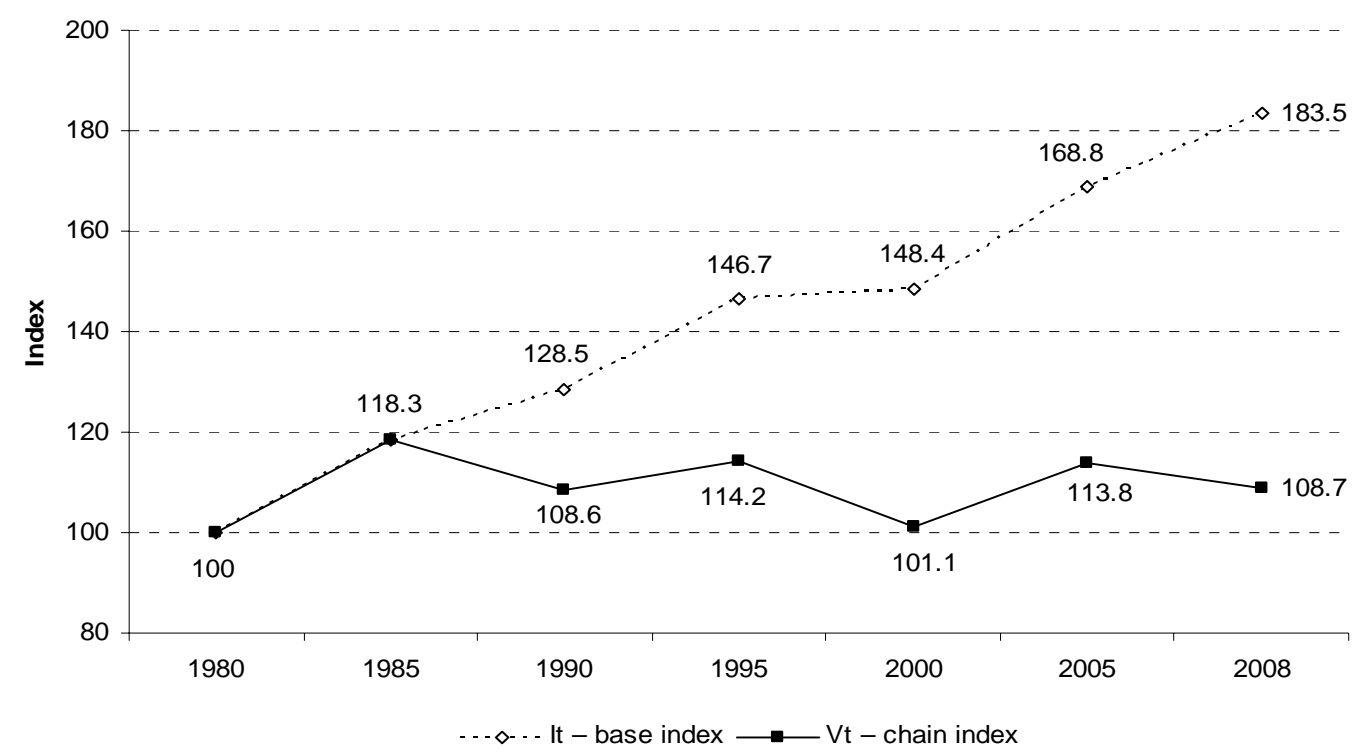

Fig. 1 Base index $(\mathbf{1 9 8 0}=100)$ and chain index for the purchases of the electrical energy by the Slovenian households, 1980-2008

Data source: Authors' calculations.

\subsubsection{Distribution of electricity consumption by households}

Electricity consumption by the Slovenian households has increased per capita, per household, and per $\mathrm{km}^{2}$ of the Slovenian territory (see Table 2). The intensity of the electricity consumption by households is the highest in the region of the Slovenian capital of Ljubljana (see Table 3). These developments are also consistent with the population density.

Table 2 Average purchases of the electrical energy by the Slovenian households, 1980-2005

\begin{tabular}{cccc}
\hline & $\begin{array}{c}\text { Average monthly consumption per } \\
\text { capita (MWh per capita) }\end{array}$ & $\begin{array}{c}\text { Average monthly consumption per } \\
\text { household (MWh per household) }\end{array}$ & $\begin{array}{c}\text { Average annual consumption per km }{ }^{2} \\
\left.\text { in Slovenia (MWh per km }{ }^{2}\right)\end{array}$ \\
\hline 1980 & 75.9 & 237.8 & 87.4 \\
1985 & 86.8 & 257.5 & 103.4 \\
1990 & 93.1 & 262.7 & 112.3 \\
1995 & 106.8 & 291.7 & 128.2 \\
2000 & 108.0 & 288.4 & 129.0 \\
2005 & 122.1 & 316.1 & 146.8 \\
\hline
\end{tabular}

Data source: Authors' calculations.

Table 3 Consumption of electrical energy by the Slovenian households per $\mathbf{k m}^{2}\left(\mathrm{MWh}\right.$ per $\left.\mathbf{k m}^{2}\right)$

\begin{tabular}{ccccccc}
\hline & Electro Celje & Electro Gorenjska & Electro Ljubljana & Electro Maribor & Electro Primorska & Average for Slovenia \\
\hline 1980 & 68.7 & 102.6 & 120.4 & 95.5 & 49.5 & 87.4 \\
1985 & 83.4 & 117.3 & 143.5 & 113.0 & 57.1 & 103.4 \\
1990 & 92.6 & 121.2 & 150.5 & 127.0 & 65.5 & 112.3 \\
1995 & 106.7 & 133.8 & 166.2 & 149.5 & 78.6 & 128.2 \\
2000 & 107.3 & 131.4 & 169.5 & 154.4 & 77.4 & 129.0 \\
2005 & 121.2 & 149.0 & 190.9 & 173.5 & 93.6 & 87.4 \\
\hline
\end{tabular}

Data source: Authors' calculations. 
Table 4 Electricity consumption per capita (kWh per capita), 1980-2005

\begin{tabular}{ccccccc}
\hline & Electro Celje & Electro Gorenjska & Electro Ljubljana & Electro Maribor & Electro Primorska & Average for Slovenia \\
\hline 1980 & 68.0 & 104.5 & 78.6 & 68.7 & 73.9 & 75.9 \\
1985 & 79.8 & 100.0 & 93.4 & 78.6 & 84.6 & 86.8 \\
1990 & 98.1 & 107.0 & 89.6 & 87.2 & 97.0 & 93.1 \\
1995 & 121.3 & 118.4 & 99.2 & 103.1 & 108.4 & 106.8 \\
2000 & 125.9 & 114.8 & 100.5 & 106.5 & 105.6 & 108.0 \\
2005 & 143.8 & 130.9 & 112.6 & 119.0 & 122.6 & 122.1 \\
\hline
\end{tabular}

Data source: Authors' calculations.

Table 5 Average monthly consumption of electrical energy per household (kWh per household)

\begin{tabular}{ccccccc}
\hline & Electro Celje & Electro Gorenjska & Electro Ljubljana & Electro Maribor & Electro Primorska & Average for Slovenia \\
\hline 1980 & 219.2 & 295.9 & 249.0 & 222.9 & 218.0 & 237.8 \\
1985 & 243.2 & 313.9 & 269.0 & 242.6 & 232.2 & 257.5 \\
1990 & 256.4 & 305.9 & 264.1 & 255.1 & 249.8 & 262.7 \\
1995 & 287.7 & 331.5 & 283.1 & 291.2 & 291.8 & 291.7 \\
2000 & 283.5 & 323.0 & 281.2 & 294.5 & 279.1 & 288.4 \\
2005 & 311.8 & 358.8 & 302.6 & 319.1 & 323.0 & 316.1 \\
2008 & & & & & & 331.1 \\
\hline
\end{tabular}

Data source: Authors' calculations.

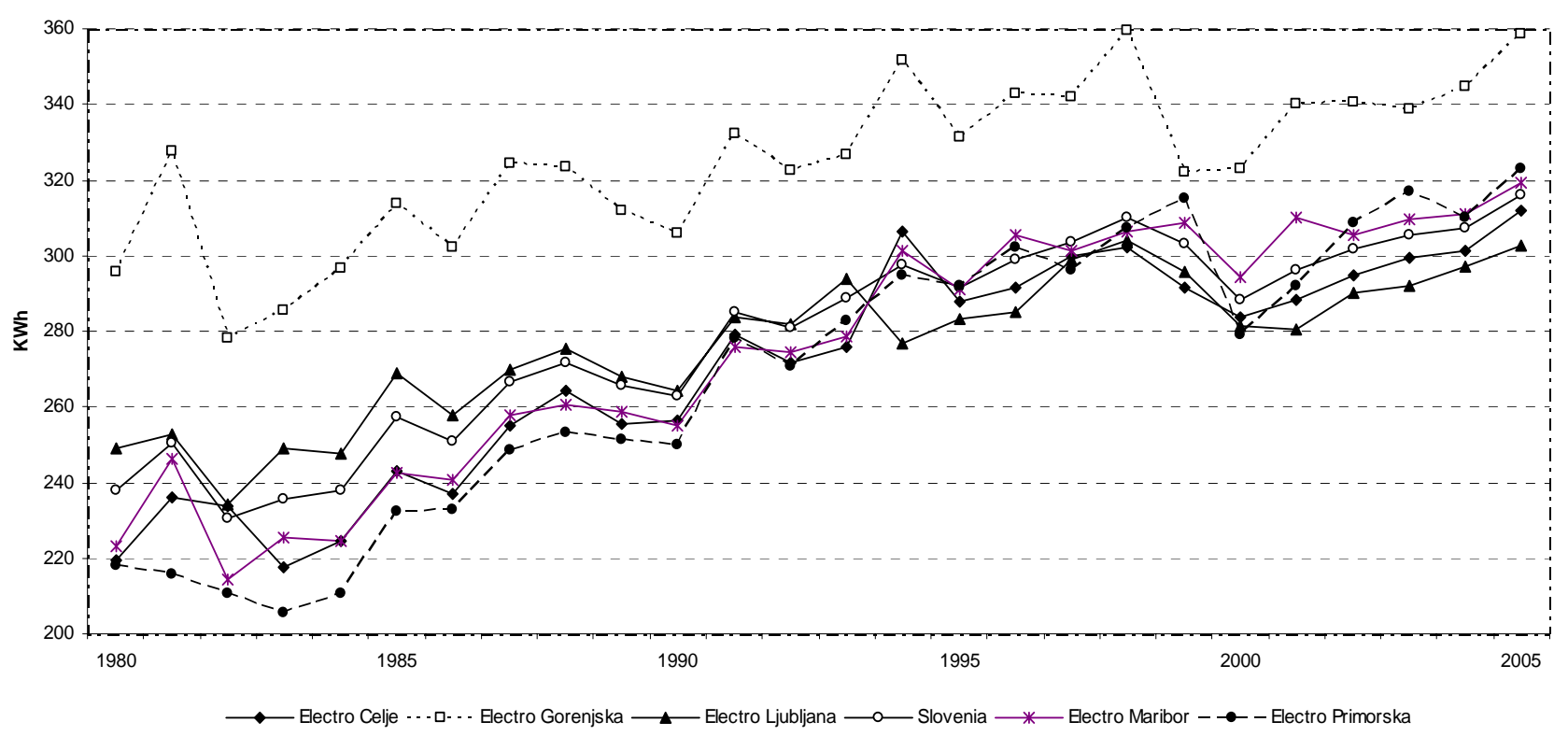

Fig. 2 Average supply of electrical energy per household by electricity distribution enterprises in Slovenia, 1980-2005

Data source: Authors' calculations.

In 2005, electricity consumption per capita of the Slovenian households by the five retail electricity distribution enterprises in Slovenia was the highest on the territory of the Electro Celje (see Table 4).

The monthly electricity consumption by households is the highest in the Electro Gorenjska region (see Table 5). In general, electricity consumption per household tends to increase over time with some oscillations by the 
individual analysed years. As clearly depicted in Fig. 2, in the initial years of transition from the previous system to a market economy at the end of the 1980s and the early 1990s, there is a decline in the electricity consumption per household particularly in 1989 and in 1990, but there is recovery after that.

\subsubsection{Market segmentation by the installed connection power and electrical energy consumption}

The Slovenian households are according to the electricity technical conditions classified into three basic tariff groups: First, it is for the basic use of electrical energy with the connection power up to $3 \mathrm{~kW}$ and with the uniform tariff rate for measuring the electrical energy consumption. Second, it is for different uses of the electrical energy in households with the connection power up to $7 \mathrm{~kW}$ and with the combined uniform-tariff and two-tariff rates for measuring the electrical energy consumption. Third, it is for the above-standard uses of the electrical energy in households with the connection power up to $10 \mathrm{~kW}$ and with the combined uniform-tariff and two-tariff rates for measuring the electrical energy consumption.

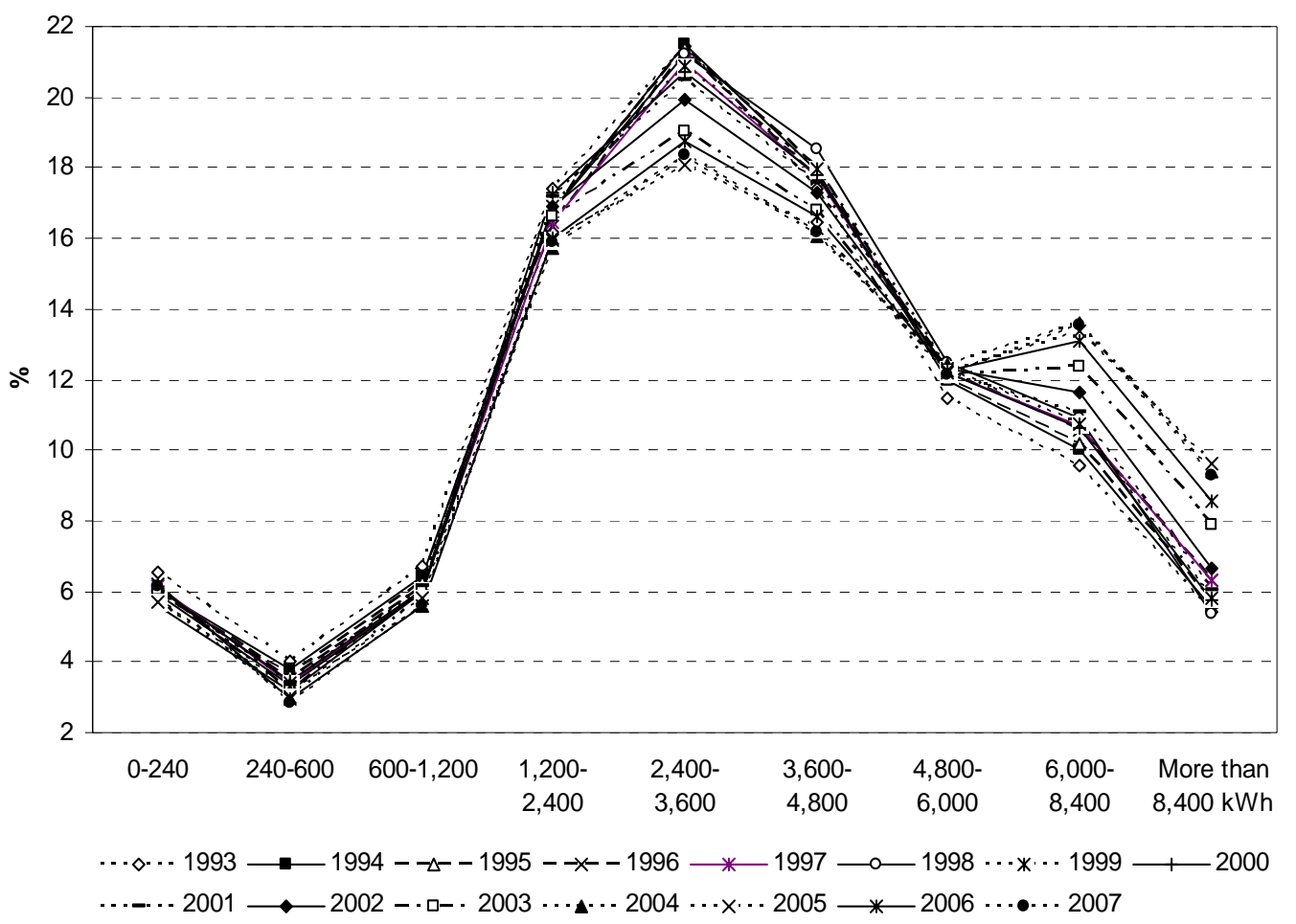

Fig. 3 Relative frequency distribution of the Slovenian households by the quantity uses of the electrical energy, 1993-2007

Data source: Authors' calculations.

Fig. 3 presents the frequency distribution of the Slovenian households by the quantity consumption of the electrical energy. The most frequent group of the households by the quantity of the electrical energy consumption are with the annual average consumption between 2,400 and 3,600 $\mathrm{kWh}$, and after that with the annual average consumption between 3,600 and 4,800 $\mathrm{kWh}$, and between 1,200 and 2,400 $\mathrm{kWh}$. There has been an increasing frequency in the electrical energy consumption for the households, which are the largest users of the electrical energy. This is consistent with the shift in the number of households from the medium-sized consuming households to the large-sized consuming households of the electrical energy, while there are less significant changes for the households, which are the smaller users of the electrical energy.

3.1.4 Electricity consumption by households' tariff rates 
Households' electricity consumption in Slovenia has increased by $16.2 \%$ during the period 2002-2008 (see Fig. 4). By the quantity of the electricity consumption, the second tariff group containing the middle-sized households' electricity consumers is the most significant in Slovenia. The reasons for that are in their largest number.

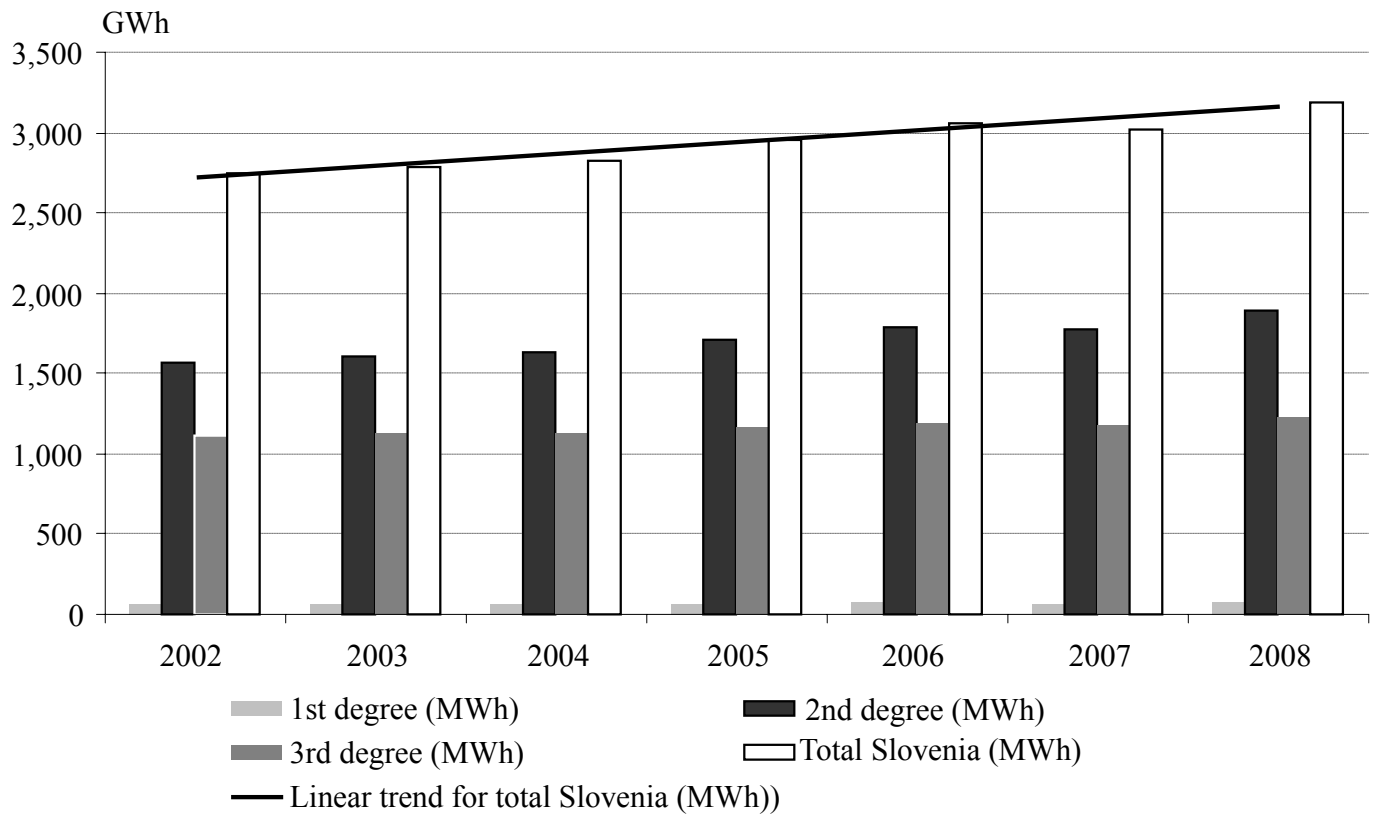

Fig. 4 Growth of electricity consumption by households' tariff rates in Slovenia, 2002-2008

Data source: Authors' calculations.

As expected, the electricity consumption per household has increased over time and by the electricity connection power of the households (see Table 6). It is the lowest for the 1st tariff rate and about four times greater for the 3rd tariff rate. Only the latter group has the average monthly electricity consumption per household, which is the above of the Slovenian average.

Table 6 Average monthly consumption of electrical energy by three different tariff rates of households, 2003-2008 (kWh/household)

\begin{tabular}{lllllll}
\hline & 2003 & 2004 & 2005 & 2006 & 2007 & 2008 \\
\hline 1st tariff rate & 107.1 & 107.1 & 114.1 & 118.9 & 114.1 & 121.7 \\
2nd tariff rate & 274.5 & 275.7 & 282.9 & 294.1 & 283.3 & 295.9 \\
3rd tariff rate & 417.1 & 425.6 & 437.7 & 451.5 & 445.5 & 464.8 \\
Average for Slovenia & 305.6 & 308.0 & 316.1 & 327.4 & 317.6 & 331.1 \\
\hline
\end{tabular}

Data source: Compiled by the authors on the basis of data obtained from Directorate of Energy, Ministry of the Economy of Slovenia.

\subsection{Concentration of households by electricity consumption}

\subsubsection{Lorenz curve of concentration}

The Lorenz curve of market concentration for electricity consumption by households shows that $50 \%$ of the Slovenian households consumed $80 \%$ of electrical energy in households (see Fig. 5). The concentration has not changed significantly over time, and there is also not a significant difference in the concentration by different retail electricity distribution enterprises as for example for the Electro Gorenjska, which is one of the retail 
distribution enterprises in Slovenia, and for Slovenia as a whole.

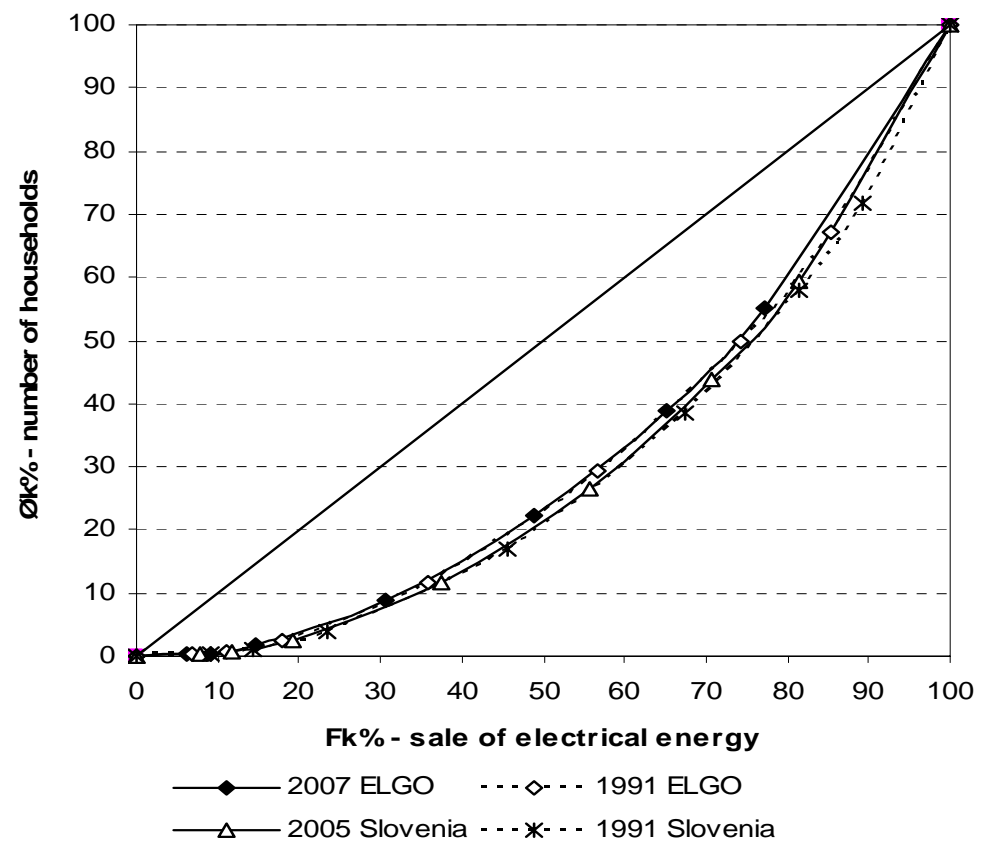

Fig. 5 Lorenz curve for households' concentration by the purchases of the electrical energy in Slovenia and from the Electro Gorenjska (ELGO) for the years 1991, 2005 and 2007

Data source: Authors' calculations.

Note: $\phi_{k} \%$ means cumulative of relative totals of number of households and $\mathrm{Fk} \%$ means share of cumulative frequency (\%) of sale of electrical energy.

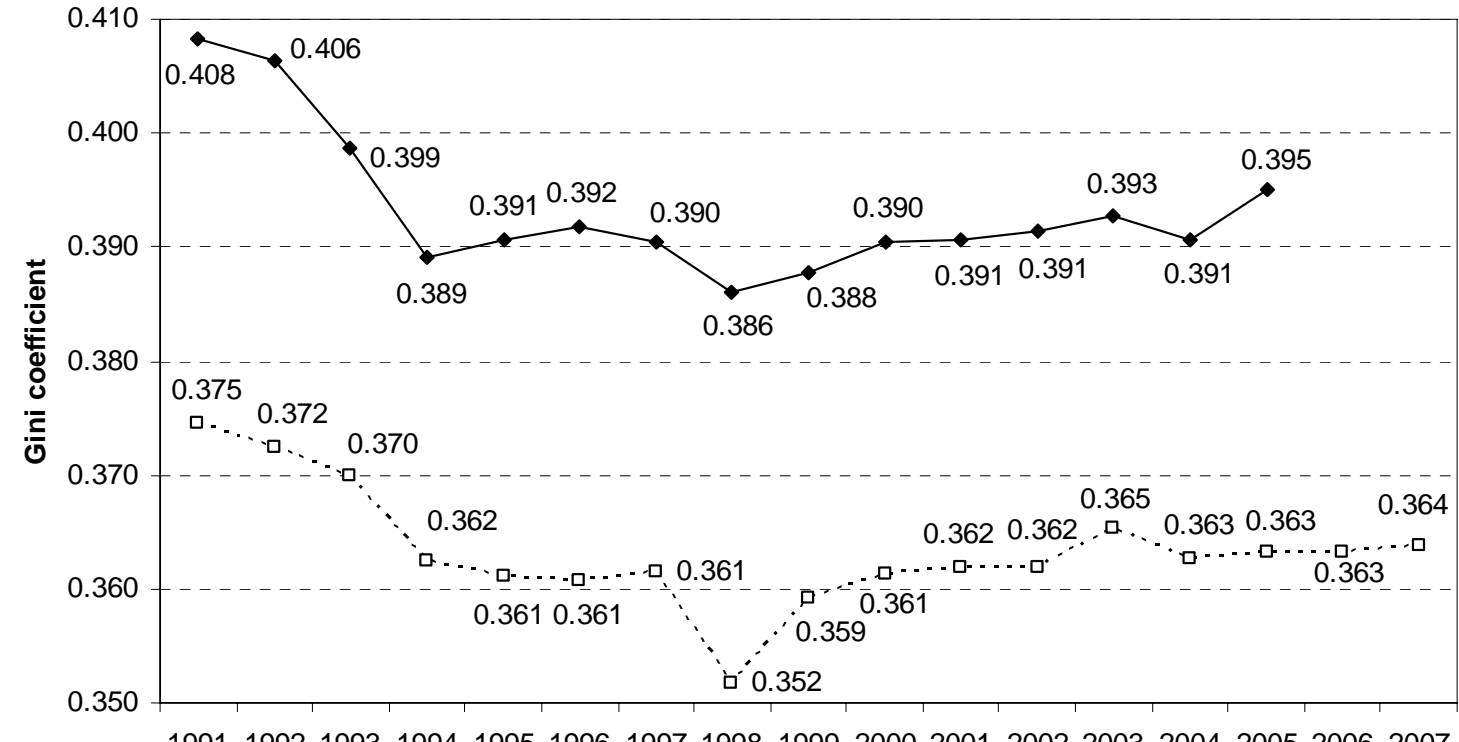

$\longrightarrow$ Slovenia ........ ELGO

Fig. 6 Gini coefficient of concentration of households by the purchases of the electrical energy from the retail distribution enterprises in Slovenia and from the Electro Gorenjska (ELGO), 1991-2007

Data source: Authors' calculations. 


\subsubsection{Gini coefficient of concentration}

The Gini $(G)$ coefficient of concentration of households' by the electricity consumption shows greater concentration for the Slovenian average than for the Electro Gorenjska (ELGO) (see Fig. 6). The $G$ coefficient indicates a modest concentration of the households' electricity consumption. A slight decline in the concentration of the households' electricity consumption can be seen by the retailing electricity suppliers in Slovenia during the years 1991-2005.

\subsection{Prices of electrical energy for households}

Five different prices of electrical energy for households (from $D a$ to $D e$ ) have been introduced in the European Union (EU) countries, including in Slovenia, which became EU member in 2004, considering the quantity of the consumption of the electrical energy and the connection power. The results for Slovenia indicate a slight variation in the real household electricity price developments during the government regulations of these prices (see Fig. 7). Since the price deregulation in July 2007, there has been an initial decline, but later a slight increase in their real values.

The impact of the electrical energy price deregulation on the patterns in the electricity price developments for households for the standard household tariff group $D c$ can be seen from Fig. 8. There are seen some differentials in the level and development of real electrical energy prices between different retailers, but in general real electricity prices for households have had an increasing tendency.

\subsection{Demand function for electricity consumption by households}

The empirical results show that the household electricity consumption is positively and statistically significantly associated with the households' income, and negatively associated with the real price of the electrical energy for the higher tariff rate for the households (see Table 7). The partial elasticity coefficient for the former is inelastic, but elastic for the latter. The other tested elasticity coefficients for other initially specified explanatory variables have turned out not to be either of an expected sign or have been found as a statistically insignificant.

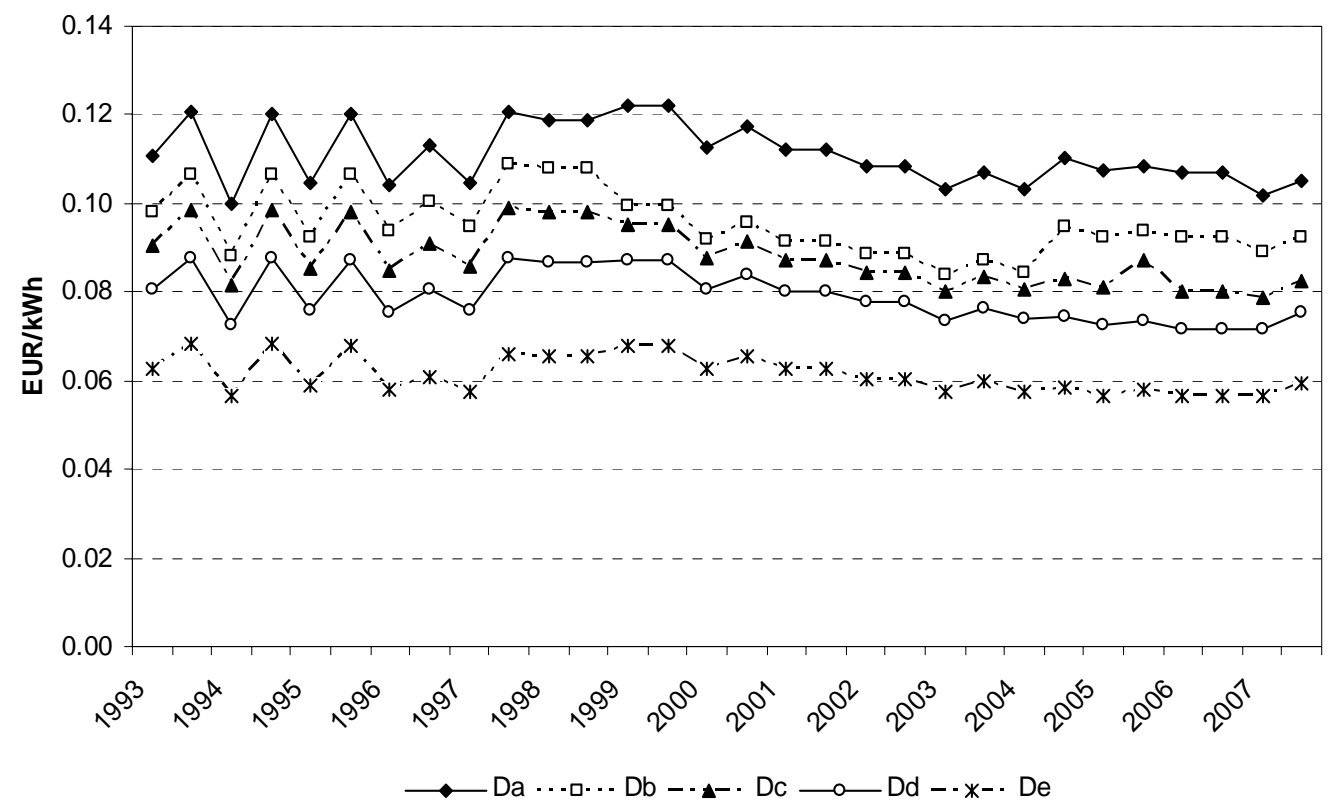

Fig. 7 Real prices of electrical energy for households in Slovenia, 1993-2007 (the 2003 base year)

Data source: Authors' calculations. 


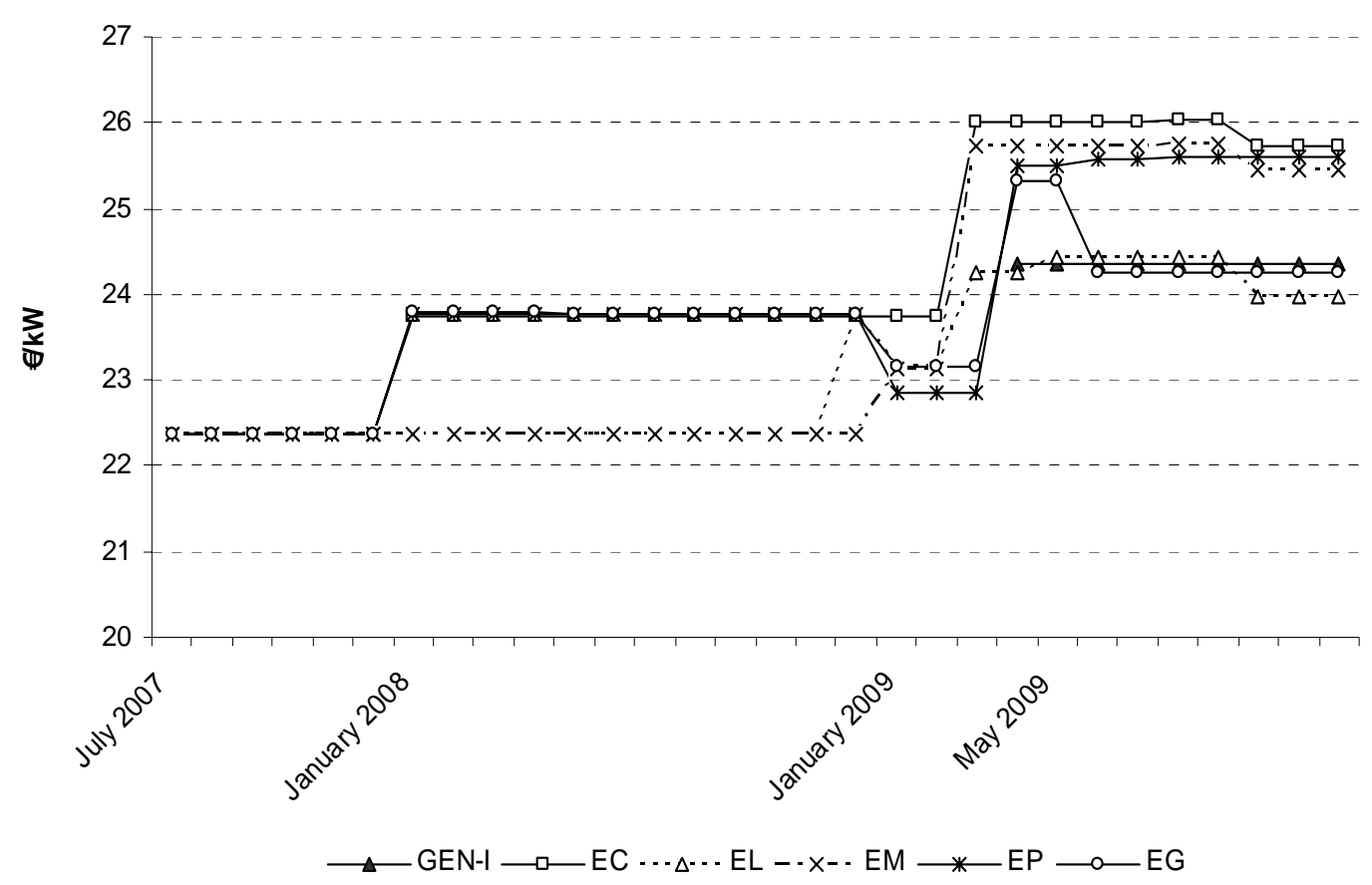

Fig. 8 Prices of electrical energy Dc for households in Slovenia, July 2007-June 2009

Notes: EC: Electro Celje, EL: Electro Ljubljana, EM: Electro Maribor, EP: Electro Primorska and EG: Electro Gorenjska.

Data source: Authors' calculations.

Table 7 Demand function for electricity consumption by households in Slovenia, 1993-2008

\begin{tabular}{cccccc}
\hline & Ln (constant) & $\operatorname{Ln}\left(\mathrm{W}_{\mathrm{h}}\right)$ & $\mathrm{Ln}\left(\mathrm{P}_{\mathrm{h}_{\_} \mathrm{HT}}\right)$ & $\operatorname{Adj}^{2}$ & $\mathrm{~F}$ \\
\hline $\mathrm{Ln}\left(\mathrm{D}_{\mathrm{h}}\right)$ & 3.119 & 0.299 & -1.219 & 0.996 & 1155 \\
& $(-16.568)$ & $(2.739)$ & $(-25.008)$ & & \\
\hline
\end{tabular}

Note: $\ln$ —natural logarithm. In the brackets are $t$-statistics.

\section{Conclusion}

The authors have investigated the electricity market for households in Slovenia. The medium-sized group by the quantity of the electricity consumption and the connection power is found as the most significant household consumer's group. Market concentration measures suggest lower degree to a modest concentration of the retail suppliers of the electrical energy to the Slovenian households. This concentration at the Slovenian market is still largely pertained to the local geographic territory of the retail electricity supplier, where the market concentration is much larger.

Market liberalization and entry of new competitors in the retail electricity distribution markets for households have slightly caused variations in the patterns in real electricity price developments for households. Households' real income and real retail electricity prices for households are the crucial determinants for the electrical energy demands by the Slovenian households.

Among the major policy implications and challenges for future research are how the most recent market liberalisation and expected increasing competitive pressures, including from import competition with electricity trade liberalisation, might cause the real retail electricity price developments for households and their transmission 
into the electrical energy demand and consumption by households with possible substitution effects in the household's energy consumption.

\section{References:}

Bojnec, Š. \& Papler, D.. (2005a). Deregulation of electricity distribution market in Slovenia. In: Proceedings of the 6th International Conference of the Faculty of Management Koper, Congress Centre Bernardin, Slovenia, 24-26 November, 2005, 315-325.

Bojnec, Š. \& Papler, D.. (2005b). Does market liberalization lead to price declines? The case of Slovenian electricity distribution markets, an enterprise odyssey: Integration or disintegration. Zagreb: Faculty of Economics and Business, 63-75.

Bojnec, Š. \& Papler, D.. (2006a). Dynamics of competition and business performance in the electricity market for industry in Slovenia, advancing business and management in knowledge-based society. In: Proceedings of the 7th International Conference of the Faculty of Management Koper, University of Primorska, 449-457.

Bojnec, Š. \& Papler, D.. (2006b). Market concentration and government deregulation, from transition to sustainable development. International Conference of the School of Economics and Business in Sarajevo (ICES 2006), Sarajevo.

Bojnec, Š. \& Papler, D.. (2007). Wholesale-to-retail electricity supply management in Slovenia. MIC’07-Management International Conference 2007, 8th International Conference of the Faculty of Management.

Bojnec, Š. \& Papler, D.. (2010). Liberalisation of the electricity market: The case of Slovenia. Est-Ovest Review, forthcoming.

Green, R.. (2003). Retail competition and electricity contracts. CIRED Conference Torino.

Nillesen, P., Pollitt, H. L. \& Michael, G. (2004). The consequences for consumer welfare of the 2001-2003 electricity distribution price review in the Netherlands. CIRED Conference Torino.

Norušis, M. J.. (2002). SPSS 12.0 Guide to Data Analysis, Upper Saddle River (N.J.), Prentice Hall.

Papler, D. \& Bojnec, Š.. (2006) Pomen managementa na dereguliranem maloprodajnem trgu električne energije v Sloveniji. Management, 2(2), 115-129.

Papler, D. \& Bojnec, Š.. (2007). Electricity supply management for enterprises in Slovenia. International Journal of Management and Enterprise Development, 4(4), 403-414.

(Edited by Ruby and Chris) 